\title{
To The Editor «Dermatologica»
}

\section{Dear Sir,}

In the review of literature concerning "Erythrodermien, Sklerosen, Atrophien" etc.

(Dermatologica 121: 314 [1960]) Dr. Gutekunst writes:

"Jablońsk $\alpha$ (Brit. J. Derm. 71: 123 [1959]) vermutet, daß die Raynaudsche Gangrän nur eine Varietät der diffusen Sklerodermie darstellt."

In the paper "Acrosclerosis: a disease sui generis or a variety of diffuse scleroderma" we have tried to prove that acrosclerosis (= Raynaud's syndrome coexistent with diffuse scleroderma) is a variety of scleroderma with marked symptoms of angioneurosis but not a disease sui generis. We have stated that scleroderma may develop in long-standing Raynaud's disease, but we have never called the Raynaud's gangrene of the extremities a variety of diffuse scleroderma.

I remain, Yours faithfully S. Jablońsk $\alpha$

Corrigenda

In der Diskussionsbemerkung Prof. G. Miescher auf Seite 306 ist der Nachsatz «sodaß ich an der früher gestellten Diagnose einer Erythrokeratosis circinata variabilis festhalte» zu streichen. 